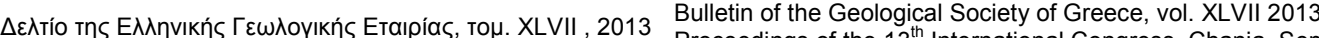
Proceedings of the $13^{\text {th }}$ International Congress, Chania, Sept.

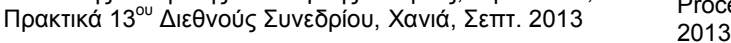

\title{
CLAY MINERALS FROM THE ARKITSA FAULT GOUGE ZONE, IN CENTRAL GREECE, AND IMPLICATIONS FOR FLUID FLOW
}

\author{
Papoulis D. ${ }^{1}$, Romiou D. ${ }^{1}$, Kokkalas S. ${ }^{1}$ and Lampropoulou $\mathbf{P}^{1}$. \\ ${ }^{1}$ University of Patras, Department of Geology,Papoulis@upatras.gr,skokalas@upatras.gr
}

\begin{abstract}
Clay minerals in shallow fault rocks are increasingly recognized as key to the mechanical and seismogenic behavior of faults and fluid flow circulation within the fault core and the surrounding damage zone. We therefore studied faultgouge mineralogy from samples derived from the ENE-trending Arkitsa fault zone, in east-central Greece, in order to testify if the fault is acting as a channel for fluid flow and whether the conditions that characterize the flow can be identified.

Clay-gouge samples were collected within the fault core zone, as well as in the broader fault damage area. Consequently, the samples were analyzed by X-Ray Diffraction, SEM and Electron microprobe analyses. The minerals that were identified within the centre of the fault zone are: Montmorillonite, corrensite, illite, micro-calcite, dolomite, quartz, plagioclase and K-feldspars. The absence of corrensite, a clay mineral usually formed in hydrothermal conditions, in the samples from the broader fault damage area indicates that the circulation of hydrothermal fluids is mostly confined within and around the fault core zone. The assemblages within the fault gouge zone and especially the presence of corrensite, combined with the absence of laumontite, indicate hydrothermal alteration at neutral to alkaline conditions and a temperature range at about $100-150^{\circ} \mathrm{C}$.
\end{abstract}

Key words: fault zone, chlorite/smectite, hydrothermal fluids, fault damage

\section{Пврі́ $\eta \psi \eta$}

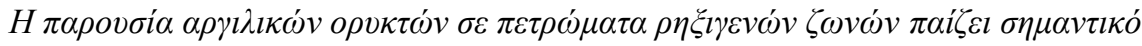

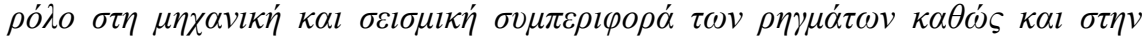

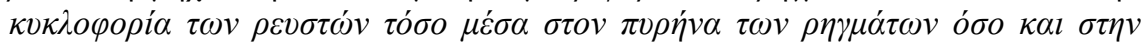

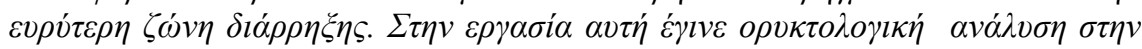

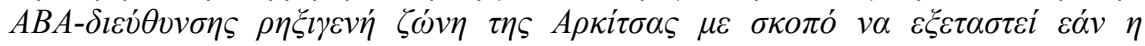

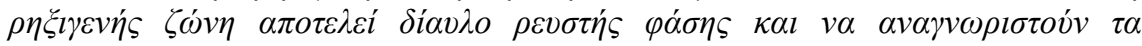

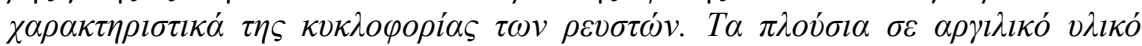

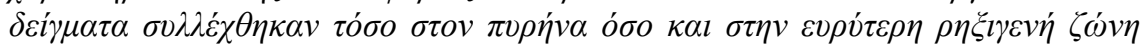

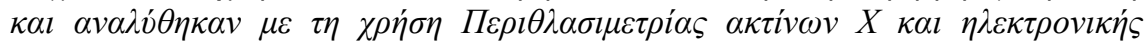

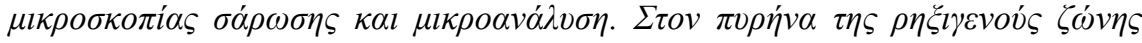

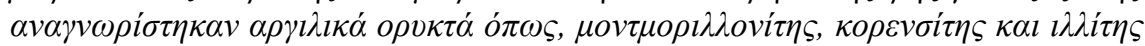

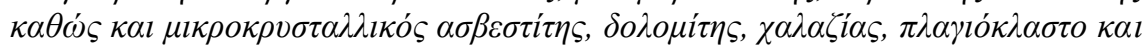

$\underline{\text { XLVII, No } 2-616}$ 


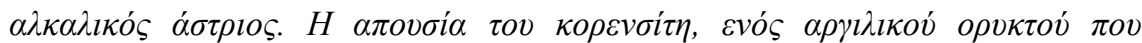

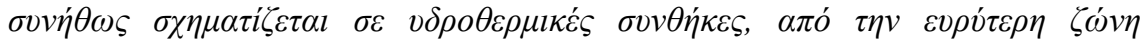

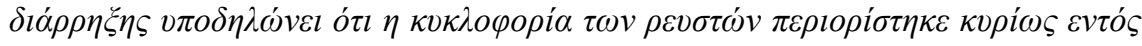

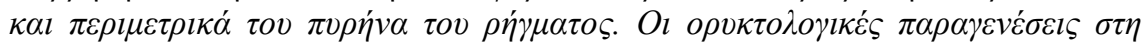

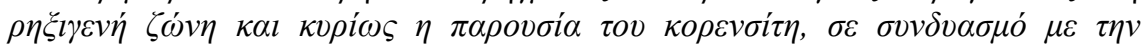

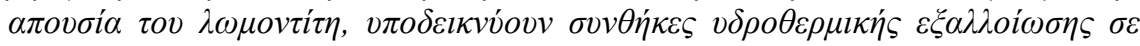

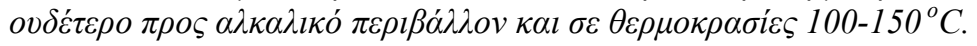

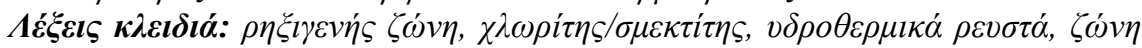
$\delta i \alpha ́ \rho \rho \eta \xi \eta \varsigma$.

\section{Introduction}

Clays have a number of rather unique properties as a consequence of clay mineral sheet silicate structure, size (nanocrystals) and in many of them, especially some of the most common, significantly charged particle surfaces. The presence of clay minerals within faults has been shown to influence significantly the flow of fluids in sedimentary basin (Knipe, 1993). Clay minerals as well as clay mineral growth affect anisotropy, permeability, porosity and fault strength (Morrow et al., 1984; Wintsch et al., 1995; Wibberley, 1999; Warr \& Cox, 2001; Solum et al., 2003).

The shear strength of drained clays and pure clay minerals show strong variations depending on particle anisotropy and layer-charge as it has been shown by many laboratory testing (e.g. Rosenquist, 1962; Rosenquist, 1984; Müller-Vonmoos \& Loken, 1989).

Clay minerals, because of their hydrous nature, can induce fluid pressure variations by storing or releasing water by hydration-dehydration reactions (Bruce, 1984; Vrolijk, 1990). This process is particularly important in the presence of smectite which can generate significant fluid pressures at low confining pressures by particle swelling (Koukouvelas \& Papoulis, 2009). Variations in the
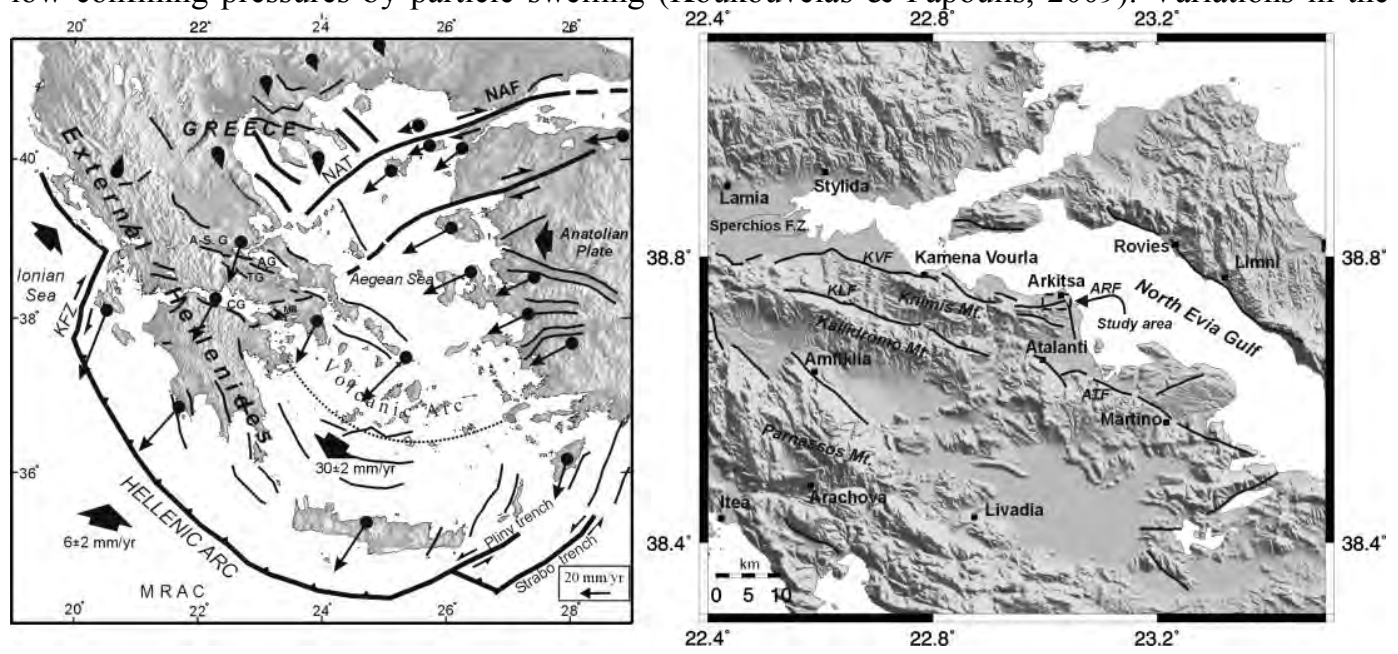

Figure 1 - (left): Simplified map showing the main structural features along the Hellenic Peninsula, as well as the main active structures. The mean GPS horizontal velocities in the Aegean plate are shown with respect to a Eurasia fixed reference frame. CG: Corinth graben, TG: Tithorea graben, AG: Atalanti graben, A-S.G: Almyros-Sperchios graben, MB: Megara basin. NAT: North Aegean Trough, NAF: North Anatolia Fault, KFZ: Kephalonia transform fault, MRAC: Mediterranean Ridge Accretionary Complex. Map modified from Kokkalas et al. (2006); (right): Map of central Greece close to the North Evia Gulf showing the main fault traces and the study area (arrow pointing to dashed rectangle). ATF: Atalanti fault, ARF: Arkitsa Fault; KLF: Kallidromo fault, KVF: Kamena Vourla fault. 
type as well as the hydration state of smectite, and therefore fluid pressure fluctuations, are strongly influenced by deformation and changes in effective pressure (Morrow et al., 1992; Fitts \& Brown, 1999; Moore \& Rymer, 2012).

The aim of this study is to testify whether the fault is acting as a channel for flow and if the conditions which characterizing the flow can be identified. Additionally we intend to estimate the rate and conditions (e.g. temperature) of fluid transportation and to investigate the influence of the presence of clay minerals during this procedure.

\section{Geological Setting of the study area}

Since the Upper Miocene to present, the area of Central Greece is currently undergoing active N-S to NE-SW regional extension, with rates on the order of 1-2 mm/yr (Clarke et al., 1998), in response to the complex tectonic interplay between subduction beneath the Hellenic Arc, back-arc extension in the Aegean, and the westward movement of the Anatolian plate (e.g. Doutsos \& Kokkalas, 2001; Kokkalas et al., 2006). In central Greece, much of the extensional strain is localised into a number of WNW-ESE trending grabens, which are mostly characterised by complex geometries in map view (Fig.1: right), and a high degree of segmentation along strike (Doutsos \& Poulimenos, 1992; Ganas et al., 1998; Kokkalas et al., 2007). Most of the major range bounding normal faults are thought to have been active in the Pleistocene, but the relative time of their activity is not well constrained. Some historical earthquakes in the region are known, but none can be directly associated with Arkitsa fault zone or any other fault with certainty, except the 1894 rupture events of Atalanti fault (Ambraseys \& Jackson, 1990).

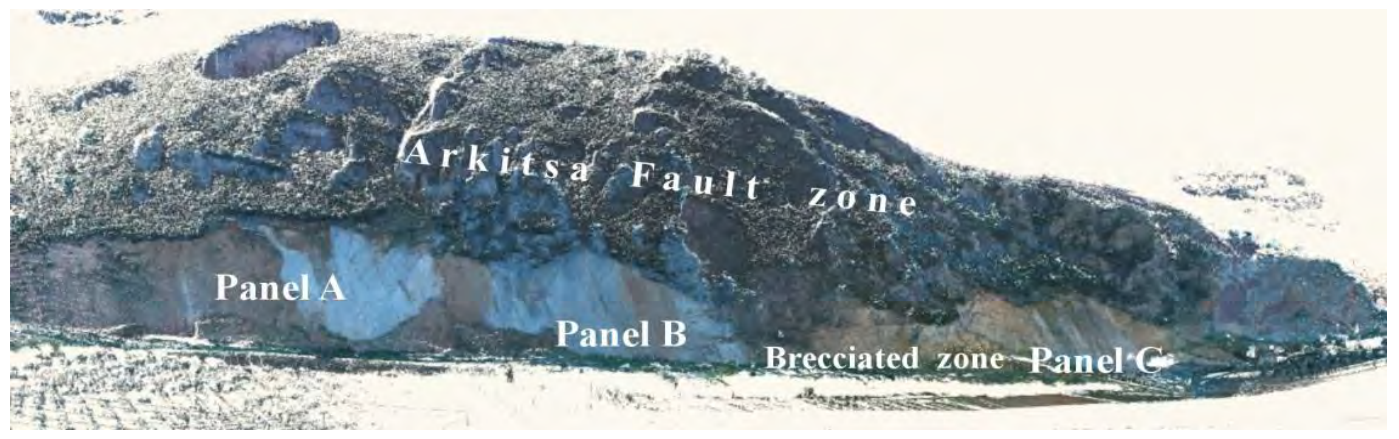

Figure 2 - Plan view image of the Arkitsa fault zone showing the three fault panels (A, B, C). The sampling area is on the left part of the picture-left part of panel A (LiDAR image; Jones et al., 2009-view towards south).

The study site for this work is the area of spectacularly exposed fault surfaces of the Arkitsa fault zone (Fig. 2), firstly reported by Jackson \& McKenzie (1999), located on the southern side of the northern Gulf of Evia in central Greece. The Arkitsa fault zone, together with Ag. Konstantinos fault and Kamena Vourla fault (KVF) towards the west, form a WNW-ESE left stepping, northdipping fault margin that link with the southern margin of the Almyros-Sperchios graben (Fig.1: right). The Arkitsa fault zone, which has a length of $\sim 10 \mathrm{~km}$, separates Late Triassic - Jurassic platform carbonates in the footwall from Lower Pliocene to Quaternary sediments in the hangingwall (Kokkalas et al., 2007). Below the carbonate units a characteristic Middle/Late Triassic volcano-sedimentary sequence is formed (Pe-Piper \& Panagos, 1989). The amount of fault throw apparently varies along strike, typical of highly segmented fault zones. A minimum throw for the Arkitsa fault zone, based on Neogene-Holocene sediment thickness on the hangingwall block plus the scarp height and topographic relief of the footwall block, is estimated to be around $500-600 \mathrm{~m}$ (Jones et al., 2009). Thus, a slip rate of $0.2-0.3 \mathrm{~mm} / \mathrm{yr}$ can be calculated for Arkitsa fault zone, taking into account that faults of Evia rift zone started their activity in the last 2-3 My (Ganas et al., 1998). 
The Arkitsa fault is best exposed in an outcrop $500 \mathrm{~m}$ south of the main Athens - Lamia national road, where recent quarrying activity during the last 20 years has removed most of the hangingwall colluviums, revealing fresh exposures of the upper $\sim 65 \mathrm{~m}$ of three large fault panels (Kokkalas et al., 2007). The geomorphological expression of Arkitsa area, the back-tilted terraces on the Arkitsa fault hangingwall block, as well as the fresh $\sim 1 \mathrm{~m}$ band of unweathered limestone at the contact between the scree and fault plane before the quarrying, suggest Holocene seismic activity along this fault.

\section{Sampling and Analytical Methods}

Three clay-gouge samples were collected within the fault core zone both from the centre and the periphery (Ar11, Ar12, Ar13; Fig.3a, b). In order to compare the mineralogy of the clay gouge zone with the colluvial sediments outside the fault, two representative samples were collected from the broader fault damage area (Ar4, Ar6; Fig. 3a).

The mineralogical analyses of the samples were conducted by X-ray diffraction (using a Bruker D8 advance diffractometer, with Ni-filtered and $\mathrm{CuK} \alpha$ radiation). XRD patterns were obtained from oriented or random powder samples in a $2 \theta$ range of $2^{\circ}$ to $60^{\circ}$ at a scanning rate of $2 \% \mathrm{~min}$. Random powder mounts of selected samples were prepared by gently pressing the powder into the cavity holder. Oriented clay powder samples were prepared by the dropper method.
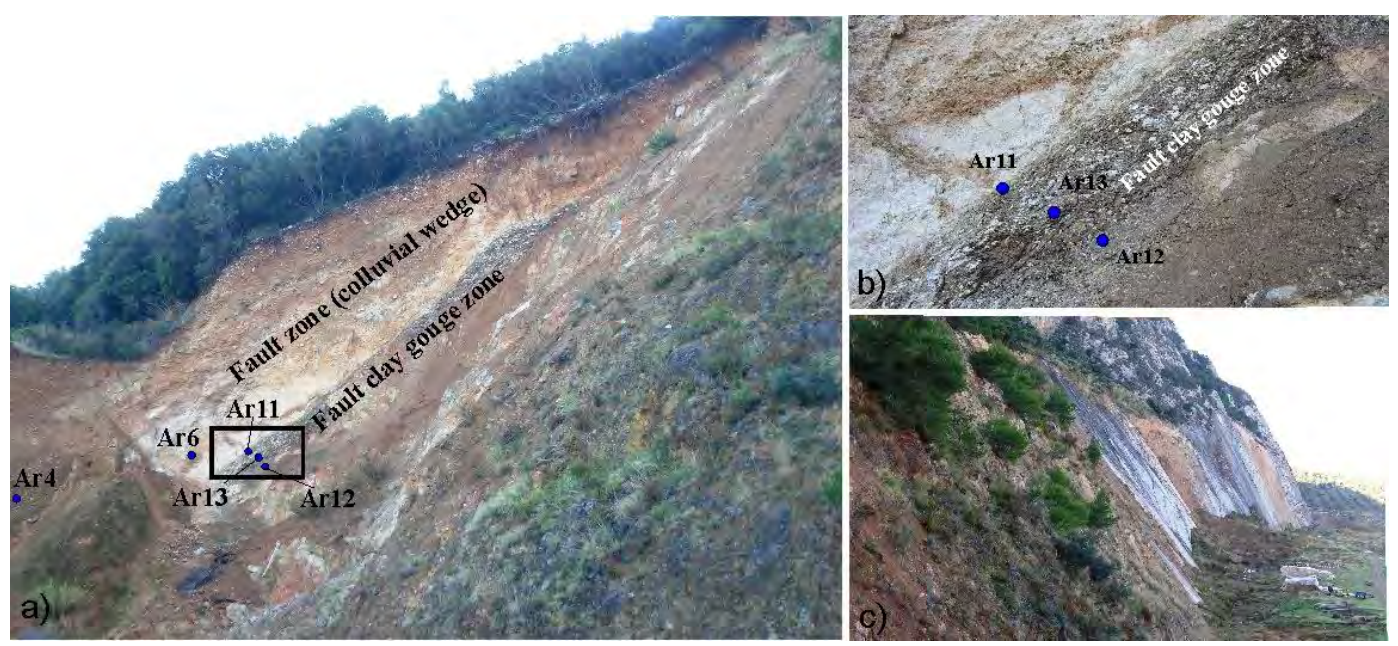

Figure 3 - (a) View of the Arkitsa Fault gouge zone and the colluvial wedge deposits adjacent to the eastern part of the scarp with sample locations. Rectangle shows the detailed area of Fig.3b (b) Detailed view of the fault clay gouge zone with location of the samples. (c) Side view of Arkitsa fault scarp showing the two of the three curved fault panels and the fault gouge zone between them.

Minerals morphology and chemical composition were examined using a Scanning Electron Microscope (SEM) JEOL 6300 equipped with an Energy Dispersive Spectrometer (EDS). The chemical composition of the minerals was determined using natural and synthetic standards and $20 \mathrm{kV}$ accelerating voltage with $10 \mathrm{nA}$ beam current. Microanalyses were performed on epoxy resin-impregnated polished and carbon or gold coated thin sections and sample powders mounted directly on the sample holder. In order to verify our results, minerals morphology and their chemical composition were also examined by using a SEM LEO SUPRA 35VP. 


\section{Results and Discussion}

The mineralogical analyses of the collected samples were conducted by a combination of X-Ray Diffraction, SEM and Electron microprobe analyses (Figs 4, 5 and 6). The samples from the periphery of the fault clay gouge (samples Ar11, Ar12) are characterized by the presence of smectite (montmorillonite-determined using SEM-EDS) and calcite (Fig. 4e). The minerals that were identified within the centre of the fault clay gouge zone are: Smectite, corrensite, illite, micro-calcite, dolomite, quartz, plagioclase and K-feldspars (Table 1). These minerals do not coexist but are discriminated in two different assemblages. The Ar-13 lighter color assemblage is characterized by the presence of the clay mineral corrensite, as well as smectite (saponite) and illite that coexist with dolomite and plagioclase while K-feldspars are absent (Figs 4c, d, 5a, b and $6 \mathrm{a}, \mathrm{b})$. The presence of the above assemblage is confined in a thin zone (about $1 \mathrm{~cm}$ thickness). The Ar-13, dark color assemblage is characterized by the presence of the clay mineral smectite, $\mathrm{K}$ feldspars and in small amounts of illite while plagioclase is absent (Figs $4 a, b, 5 c, d$ and 6c). It should be noted that the type of smectite, as well as the mixed-layer (corrensite in the lighter color assemblage) and K-feldspars were identified using SEM-EDS (Fig. 6). The mineralogical analyses of the samples from the broader area showed the presence of calcite and in some cases montmorillonite, while corrensite and saponite are absent (Table 1, Fig. 4f).

The presence of corrensite is considered to be very important because is a regular mixed-layer chlorite-smectite clay mineral and more specifically chlorite-saponite. The presence of a different type of smectite (montmorillonite and not saponite) in the other assemblage, within the centre of the fault clay gouge, indicates that these two different assemblages represent probably different events or procedures. This is supported by the fact that the samples from the periphery of the fault clay gouge are characterized by the presence of montmorillonite and calcite and the absence of corrensite, as well as dolomite. In any case the assemblages found within the centre of the fault clay gouge did not form at the same time or place.

Taking into consideration that corrensite is usually formed in hydrothermal environments (Meunier, 2005), its absence in the samples from the broader fault damage area indicates the circulation of hydrothermal fluids only within the fault core zone. Saponite and corrensite may have been also originated when cooling, low $\mathrm{P}_{\mathrm{H}}$ Mg-rich fluids invaded the Mesozoic platform carbonate series, that form the Arkitsa footwall, while calcite dissolution caused $\mathrm{P}_{\mathrm{H}}$ to increase. The diagenetic formation of corrensite from saponite at depth and its uplift is not the case because saponite in diagenetic conditions would rather be transformed to palygorskite, which is not observed on any sample from Arkitsa. Additionally, the diagenetic transformation of smectite to chlorite is taking place not only through corrensite but via a continuous series of mixed-layers chlorite-smectite from pure saponite (near the surface) to pure chlorite at depth. The uplift would allow us not only to trace corrensite but a series of chlorite-smectite mixed-layers, which is clearly not the case here. In hydrothermal environments, the successive disappearance of saponite and corrensite at certain depths enable the following reaction to be written: saponite $\rightarrow$ corrensite $\rightarrow$ chlorite, (Beaufort et al., 1997). It is therefore, reasonable to suggest that the formation of corrensite is hydrothermal rather than diagenetic.

The assemblages within the fault gouge zone can provide important information about the conditions of their formation. The presence of corrensite, combined with the absence of chlorite and laumontite, indicate hydrothermal formation at neutral to alkaline conditions and a temperature range at about $100-150{ }^{\circ} \mathrm{C}$ (Meunier, 2005). The presence of the above assemblage confined in a thin zone (about $1 \mathrm{~cm}$ thickness) indicates that the hydrothermal fluids were circulating only within this part of the fault zone and for a short period of time. It is therefore reasonable to assume that the hydrothermal fluids were elevated during a seismic event and from a zone at depth that reached temperatures on the order of $100-150{ }^{\circ} \mathrm{C}$. In this way the alteration was confined in a thin zone in the centre of the fault gouge where the circulation of the hydrothermal fluids was taking place. 
Table 1 - Mineralogical compositions of the studied samples within the fault clay gouge zone and two representative samples from the surrounding fault colluvial wedge.

\begin{tabular}{|c|c|c|c|c|}
\hline Sample $\mathbf{N}^{0}$ - Location & Clay Minerals & Quartz & $\begin{array}{l}\text { Calcite - } \\
\text { Dolomite }\end{array}$ & Feldspars \\
\hline $\begin{array}{l}1-(\text { Ar } 13) \text { centre of } \\
\text { the fault clay gouge } \\
\text { zone (dark color). }\end{array}$ & $\begin{array}{c}\text { Montmorillonite }+ \\
\text { illite }\end{array}$ & + & \pm Calcite & $\begin{array}{l} \pm \mathrm{K}- \\
\text { Feldspars }\end{array}$ \\
\hline $\begin{array}{l}2-(\text { Ar } 13) \text { centre of } \\
\text { the fault clay gouge } \\
\text { zone (light color) }\end{array}$ & $\begin{array}{l}+ \text { Corrensite }+ \\
\text { Saponite }+ \text { illite }\end{array}$ & + & + Dolomite & $\stackrel{+}{+}$ \\
\hline $\begin{array}{l}3-4 \quad(\text { Ar 11-Ar12) } \\
\text { lower boundary of the } \\
\text { fault clay gouge zone. }\end{array}$ & + Montmorillonite & + & + Calcite & - \\
\hline $\begin{array}{l}4 \text { (Ar 4)- Fault damage } \\
\text { zone (colluvial } \\
\text { deposits). }\end{array}$ & - & + & + Calcite & - \\
\hline 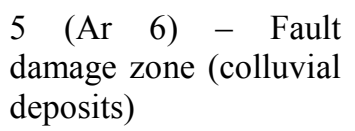 & \pm Monmorillonite & + & + Calcite & - \\
\hline
\end{tabular}

+ : Presence, $-:$ Absence, \pm : traces
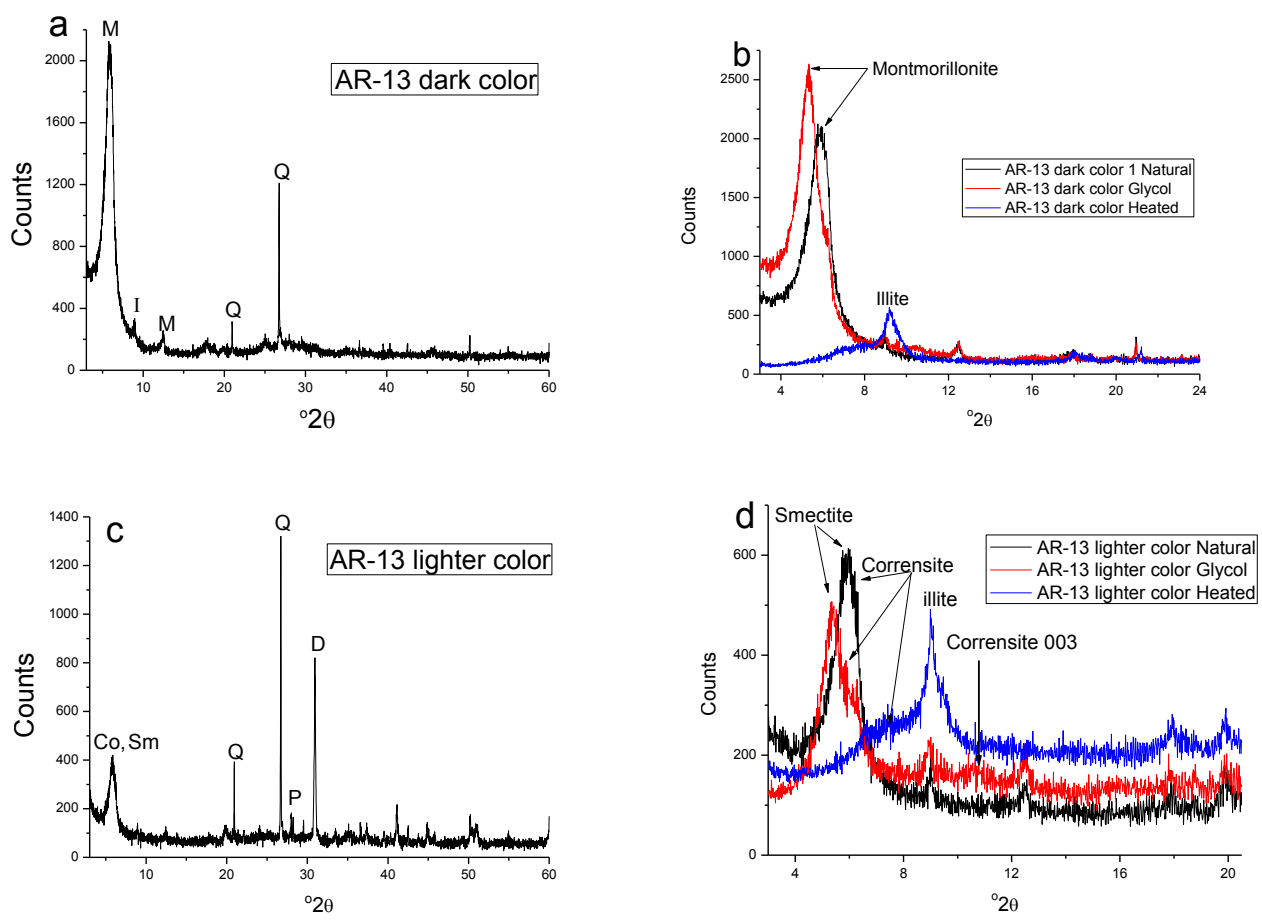

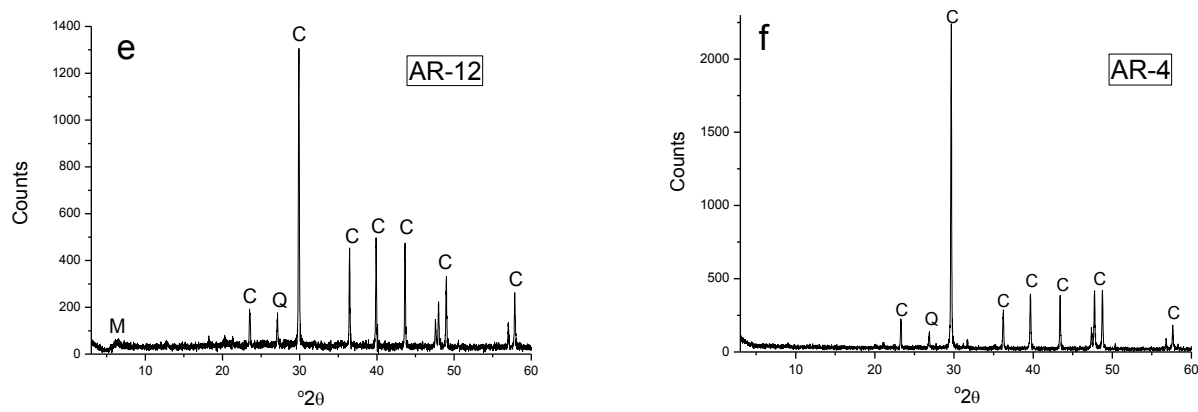

Figure 4 - XRD patterns of the assemblage Ar-13 dark color within the fault zone of bulk sample (a) and clay fraction (air dried-natural, glycolated and heated) showing the presence of smectite (b) XRD patterns of the assemblage Ar-13 lighter color within the fault zone of

bulk sample (c) and clay fraction (air dried-natural, glycolated and heated) showing the presence of smectite and corrensite (d) XRD patterns of a sample (Ar-12) from the periphery of the fault gouge showing the presence of smectite $(M)$ and calcite $(\mathrm{e})$ and of a representative

sample Ar-4 from the broader fault zone area (f) (M: montmorillonite, I: illite, Co:

corrensite, Sm: Smectite (saponite) Q: quartz, P: plagioclase, D: dolomite and C: calcite).
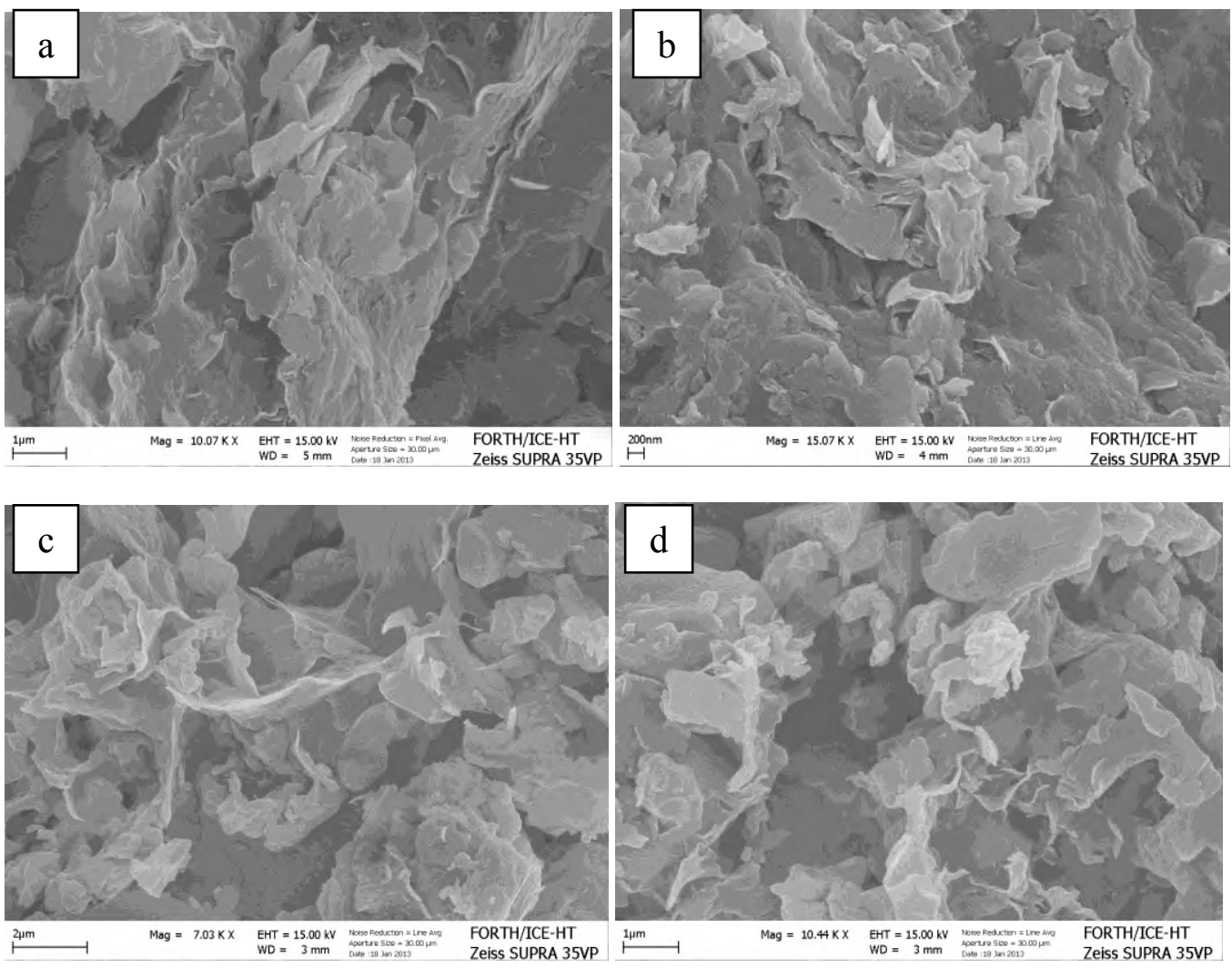

Figure 5 - SEM micrographs of (a) saponite and (b) corrensite of the assemblage Ar-13 lighter color within the fault zone (c, d) montmorillonite of the assemblage Ar-13 dark color within the fault gouge. 


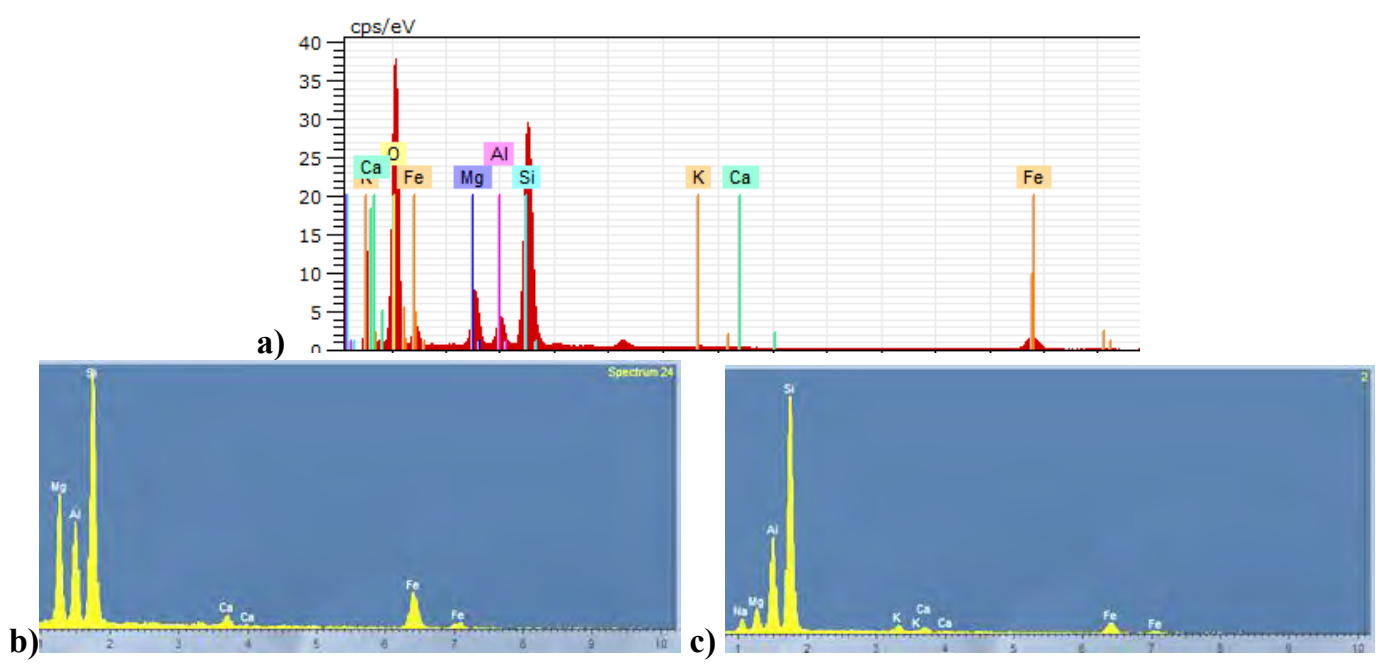

Figure 6 - SEM-EDS spectra of a) saponite and b) corrensite of the assemblage Ar-13 lighter color and c) montmorillonite of the assemblage Ar-13 darker color.

\section{Conclusions}

Clay samples were collected within the Arkitsa fault gouge zone, as well as in the broader fault damage area. The mineralogical analyses of the samples within the core of the fault zone revealed the presence of the minerals: Montmorillonite, corrensite, illite, micro-calcite, dolomite, quartz, plagioclase and K-feldspars. The absence of corrensite, a clay mineral usually formed in hydrothermal conditions, in the samples from the broader fault damage area indicates that the circulation of hydrothermal fluids was confined only within and around the fault core zone. The assemblages within the fault clay gouge zone and especially the presence of corrensite, combined with the absence of laumontite, indicate hydrothermal alteration at neutral to alkaline conditions and a temperature range at about $100-150{ }^{\circ} \mathrm{C}$. The hydrothermal alteration appears to be caused by fluids ascending from deeper zones $(\sim 3-5 \mathrm{~km})$, that circulated upwards through voids formed during a co-seismic slip event between the fault blocks.

\section{Acknowledgments}

The authors would like to thank Dr. Drakopoulos of the Foundation for Research and TechnologyHellas (FORTH) Institute of Chemical Engineering and High Temperature Chemical Processes (ICE/HT) Rio-Patras, Greece, for his help with SEM micrographs.

\section{References}

Ambraseys N. and Jackson J. 1990. Seismicity and associated strain of central Greece between 1890 and 1988, Geophys. J. Int., 101, 663-708.

Beaufort D., Baronnet A., Lanson B. and Meunier A. 1997. Corrensite: a single phase or a mixed layered phyllosilicate of the saponite-chlorite conversion series? The case study of the Sancerre-Couy deep drill-hole (France), American Mineralogist, 82, 109-124.

Bruce C.H. 1984. Smectite dehydration-its relation to structural development and hydrocarbon accumulation in Northern Gulf of Mexico basin, AAPG Bulletin, 68, 673-683.

Clarke P.J., Davies R.R., England P.C., Parsons B., Billiris H., Paradissis D., Veis G., Cross P.A., Denys P.H., Ashkenazi V., Bingley R., Kahle H.-G., Muller M.-V. and Briole R. 1998. Crustal strain in central Greece from repeated GPS measurements in the interval 19891997, Geophysical Journal International, 135, 195-214.

Doutsos T. and Poulimenos G. 1992. Geometry and kinematics of active faults and their seismotectonic significance in the western Corinth-Patras rift (Greece), Journal of Structural Geology, 14, 689-699.

XLVII, No $2-623$ 
Doutsos T. and Kokkalas S. 2001. Stress and deformation in the Aegean region, Journal of Structural Geology, 23, 455-472.

Fitts T.G. and Brown K.M, 1999. Stress-induced smectite dehydration: ramification for patterns of freshening and fluid expulsion in the N. Barbados accretionary wedge, Earth and Planetary Science Letters, 172, 179-197.

Ganas A., Roberts G. and Memou P. 1998. Segment boundaries, the 1894 ruptures and strain patterns along the Atalanti fault, central Greece, Journal of Geodynamics, 26, 461-486.

Jackson J. and McKenzie D. 1999. A hectare of fresh striations on the Arkitsa fault, central Greece, Journal of Structural Geology, 21, 1-6.

Jones R.R., Kokkalas S. and McCaffrey K.J.W. 2009. Quantitative Analysis and Visualisation of non-planar fault surfaces using Terrestrial Laser Scanning ("LiDAR") - the Arkitsa Fault, central Greece as a case study, Geosphere, v.5, no.6, 465-482.

Knipe R.J. 1993. The influence of fault zone processes and diagenesis on fluid flow. In: Horbury A.D., Robinson A.G. (eds) Diagenesis and basin development. AAPG, Studies in Geology, $36,135-148$.

Kokkalas S., Xypolias P., Koukouvelas I. and Doutsos T. 2006. Postcollisional contractional and extensional deformation in the Aegean region, in Dilek, Y., and Pavlides, S., eds., Postcollisional tectonics and magmatism in the Mediterranean region and Asia: Geological Society of America Special Paper, 409, 97-123.

Kokkalas S., Jones R.R., McCaffrey K.J.W. and Clegg P. 2007. Quantitative fault analysis at Arkitsa, Central Greece, using terrestrial laser-scanning (LiDAR), Bull. Geol. Soc. Greece, vol. XXXX, 1959-1972.

Koukouvelas I.K. and Papoulis D. 2009. Fluid involvement in the active Helike normal Fult, Gulf of Corinth, Greece, Journal of Structural Geology, 31, 237-250.

Meunier A. 2005. Clays, Springer-Verlag, pp. 473, ISBN 3-540-21667-7

Moore D. and Rymer M. 2012. Correlation of clayey gouge in a surface exposure of serpentine in the San Andreas Fault with gouge from the San Andreas Fault Observatory at Depth (SAFOD), Journal of Structural Geology, 38, 51-60.

Morrow C.A. Radney B. and Byerlee J. 1984. Permeability of sault gouge under confining pressure and shear stress, Journal of Geophysical Research Bulletin, 89, 3193-3200.

Morrow C.A. Radney B. and Byerlee J. 1992. Frictional strength and the effective pressure law of montmorillonite and illite clays. In: Evans, B and Wong, T.F. (eds) Fault Mechanics and Transport Properties of Rocks, Academic Press, New York, 69-88.

Müller-Vonmoos M. and Loken T. 1989. The shearing behaviour of clays, Applied Clay Science, 4, 125-141.

Pe-Piper G. and Panagos A.G. 1989. Geochemical characteristics of the triassic volcanic rocks of Evia: petrogenetic and tectonic implications, Ofioliti, 33-50.

Rosenquist I. 1962. The influence of physicochemical factors upon the mechanical properties of clays, Clays and Clay Minerals, 9, 12-23.

Rosenquist I. 1984. The importance of pore water chemistry on mechanical and engineering properties of clay soils, Philosophical Transactions of the Royal Society, Series A, 311, 369-383.

Solum J.G., van der Pluijm B.A., Peacor D.R. and Warr L.N. 2003. Influence of phillosilicate mineral assemblages, fabrics, and fluids on the behavior of the Punchbowl Fault, southern California, Journal of Geophysical Research, 108(B5): 5-1-5-12.

Vrolijk P. 1990. On the mechanical role of smectite on subduction zones, Geology, 18, 703-707.

War L.N. and Cox S. 2001. Clay mineral transformations and weakening mechanisms along the Alpine Fault. New Zeland, Geological Society of London, Special Publication, 186, 85-101.

Wibberley C. 1999. Are feldspar-to-mica reactions necessarily reaction-softening processes in fault zones? Journal of Structural Geology, 21, 1219-1227.

Wintsch R.P., Christoffersen R. and Kronenberg A.K. 1995. Fluid-rock reaction weakening of fault zones, Journal of Geophysical Research, 100(B7): 13021-13032. 